\title{
Maize in the Rainfed Areas of Pakistan: An Analysis for Production Sustainability
}

\author{
KALBE ABBAS, HABIB IQBAL JAVED, and SAJJAD-UR-REHMAN CHUGHTAI
}

\section{INTRODUCTION}

The turning issue in agriculture of this era is sustainability and self reliance. There are several definitions of sustainability described by various scientists. Broadly, it means that the improvement in agriculture should be long lasting in view of changing environmental and socio-economic conditions. The high yielding technology available today is not fully adopted because of high cost and changing price structure of the important inputs. Under the present circumstances, the need arises to tailor the production practices according to the need of the farmers for long-term adoption. Sustainable agricultural systems are those that rely on lower inputs of energy and agricultural chemicals to achieve long-term productivity and environmental compatibility. However, Balanos (1998) concludes that the low input systems are low in productivity. Firebaugh (1990) mentioned the proposals given by J.F. Pars and colleagues that the ultimate target of the farmers in sustainable agriculture is to increase productivity and profitability. He also added that we should get benefit from germplasm which can survive over a long period of time.

Maize, the major crop of the rainfed areas during summer season, is consumed as food, fodder and feed and have so many industrial uses. The scientists have been trying to search ways for enhanced production of maize under rainfed conditions. Reeves (1997) endorsed the findings of Pinstup-Anderson and Pandya-Lorch that the application of the results of agricultural research in the world is meant for enhanced food production, higher yields with reduced risks, lower production costs and ultimately for lower food prices which have benefited both rural and urban poor people. Dowswell et al. (1996) mentioned that the seed of improved variety and fertiliser are of over riding importance to the modernisation process. Chaudhry et al. (1989) concluded that maize

Kalbe Abbas is Research Economist at Pakistan Institute of Development Economics, Islamabad. Habib Iqbal Javed and Sajjad-ur-Rehman Chughtai are Senior Scientific Officers at National Agricultural Research Centre, (NARC), Islamabad.

Authors' Note: The excellent typing of Mr Mohammad Yousaf is appreciated. The authors are, however, responsible for any errors and omissions in the paper. This paper is a revised version of the paper presented in the 14th Annual General Meeting and Conference of PSDE. 
yield per unit area could be enhanced with high yielding variety and soil fertility. CIMMYT (1994) mentioned that seed of improved variety increased the maize productivity in many developing countries. In Pakistan, improved variety of maize outyielded local farmer's variety by 62 percent [Chand and Longmire (1990)].

Majority of the farmers in rainfed areas are poor and have small landholdings. They do not invest much in agriculture, especially in maize. For such areas, an attempt has been made to identify some economical and relatively cheaper method of growing maize so that productivity of maize could be sustained for longer period. The issue of sustainability in maize under rainfed conditions is very important. Okigbo (1990) say, "sustainability can be achieved only when resources, inputs and technology involved are within the capabilities of farmers to achieved desired level of productivity in perpetuity without adverse effect on the resource base and environmental quality".

Section 2 describes the methodology and the procedure used. The description of results is presented in Section 3. Concluding remarks with some policy options are summarised in the last section.

\section{METHODOLOGY}

A superimposed maize trial was conducted at five locations in Islamabad Capital Territory (ICT) of Pakistan. The trial was conducted in single replication at each location. The trial comprised of the following production inputs superimposed in existing farmer's practices: Variety alone $\left(T_{1}\right)$, Fertiliser alone $\left(T_{2}\right)$, Herbicide alone $\left(T_{3}\right)$, Variety plus Fertiliser $\left(T_{4}\right)$, Variety plus Herbicide $\left(T_{5}\right)$, Fertiliser plus Herbicide $\left(\mathrm{T}_{6}\right)$, Variety plus Herbicide plus Fertiliser $\left(\mathrm{T}_{7}\right)$ and Farmer's practice $\left(\mathrm{T}_{8}\right)$.

In the respective treatments, the seed of improved open pollinated variety (Agaiti-85) was planted at a seed rate of $30 \mathrm{~kg} / \mathrm{ha}$, the rate of fertilisers applied as nitrogen-phosphorus was $120-60 \mathrm{~kg} / \mathrm{ha}$ and herbicide (Primextra) was used as a preemergence herbicide @ 2.0 litre/ha. The farmers planted their own local variety with their traditional methods which is with high seed rate and without application of fertiliser and herbicide, termed as check, and was used as the baseline for the comparison. They did one seel (inter-culture of maize crop with tractor-mounted cultivator) at about 3-4 leaf stage of the crop. The crop was planted by the farmers themselves according to the instructions. The improved inputs were weighed and applied by working scientist. All other cultural practices were almost the same at all locations. The environmental conditions for all the treatments were the same at every location. At maturity, the data regarding grain yield, stalk yield, and plant density were recorded. Data were subjected to statistical analysis keeping the locations as replications under Ramdonised Complete Block Design (RCBD). Economic analysis was done in 1992, and was revised in 1997 after collection of current information about the cost of inputs, grains and fodder from local market. Assuming that the cost of production inputs increases at the same rate as in 1997, the projections for the next five years have also 
been made. The revised analysis is to see the most sustainable variable which can be utilised and sustained over the years in the next century without/or with less increase in the costs. The conclusions would be drawn on the basis of cost benefit analysis.

\section{EMPIRICAL FINDINGS}

The data regarding grain and stalk yields are statistically significant. The treatments with combination of two and three inputs are statistically at par to each other. The combination of all the three inputs $\left(\mathrm{T}_{7}\right)$ produced maximum and resulted in an increase of 43 percent and 79 percent in grain and stalk yields over the check, respectively. Javed et al. (1994) also studied this combination and observed 89 percent increase in grain yield. The combination of more contributing inputs i.e., variety and fertiliser $\left(T_{4}\right)$ which shows 38 and 62 percent increase, respectively. The combination of improved seed and fertiliser used by Dorich et al. (1987); Arain et al. (1989); Dowswell et al. (1996) and Chaudhry et al. (1989) showed similar results. These two inputs in combination with herbicide $\left(T_{5}\right.$ and $\left.T_{6}\right)$ show the same increased effect (31 percent) on grain yield but different effect (74 and 45 percent, respectively) on stalk yield. Tareen et al. (1990) observed 18 percent increase in grain yield during a study of weed control. Variety and fertilizer individually $\left(\mathrm{T}_{1}\right.$ and $\mathrm{T}_{2}$ ) show statistically non-significant differences from $T_{5}$ and $T_{6}$ and have almost the same effect of 19 and 20 percent increase in grains and 24 and 26 percent increase in stalks, respectively. These results are in line with those reported by Daskalou (1986); CIMMYT (1989); CIMMYT (1994); Chand and Longmire (1990). Herbicide alone produced 9 percent grains and 17 percent stalks more than check. Khaliq and Hussain (1987) and CIMMYT (1989) reported almost similar results in their studies. It reveals from these results that variety and fertiliser play important role in increasing production in the combinations. Keeping in view the effect of selected inputs used individually and in different combinations Table 1 explains that the treatments viz. $\mathrm{T}_{1}$ to $\mathrm{T}_{7}$ gave an increase of $20,6,27,35,14$ and 30 percent per hectare in net benefit in term of rupees over farmer's practice $\left(\mathrm{T}_{8}\right)$. The maximum increase in net benefit was achieved by the combination of variety and herbicide (35 percent). Tareen et al. (1990) observed 31 percent increase in net benefit using similar combination. The combination of variety and fertiliser showed 27 percent increase in net benefit. The variable cost of Rs 880 for $T_{5}$, Rs 2500 for $T_{7}$, and Rs 1960 for $T_{4}$, are considered to be beyond the reach of farmers of the area. The next higher benefit achieved by variety alone (20 percent), involved additional cost of Rs 40 only. The inputs with comparatively higher yields with lower unit cost reduced the risks and increase the farm income. Reeves (1997) also reached at the same conclusion. Considering Dominance analysis the treatments $T_{2}, T_{3}, T_{4}$ and $T_{7}$ are dominated because of high cost involved and are not economical. On account of very high Cost-Benefit Ratio (CBR), variety alone is considered to be more beneficial and economical 
Table 1

Relative Impact of Production Inputs on Net Benefits: Based on the Costs in 1992

\begin{tabular}{|c|c|c|c|c|c|c|c|c|c|}
\hline Variables & & $\begin{array}{l}\text { Check } \\
\left(\mathrm{T}_{8}\right)\end{array}$ & $\begin{array}{l}\text { Variety } \\
\text { Alone } \\
\left(\mathrm{T}_{1}\right) \\
\end{array}$ & $\begin{array}{c}\text { Herbicide } \\
\text { Alone } \\
\left(\mathrm{T}_{3}\right) \\
\end{array}$ & $\begin{array}{c}\text { Variety plus } \\
\text { Herbicide } \\
\left(\mathrm{T}_{5}\right)\end{array}$ & $\begin{array}{c}\text { Fertiliser } \\
\left(\mathrm{T}_{2}\right)\end{array}$ & $\begin{array}{c}\text { Variety plus } \\
\text { Fertiliser } \\
\left(\mathrm{T}_{4}\right)\end{array}$ & $\begin{array}{c}\text { Fertiliser plus } \\
\text { Herbicide } \\
\left(\mathrm{T}_{6}\right) \\
\end{array}$ & $\begin{array}{c}\text { Variety plus } \\
\text { Fertiliser plus } \\
\text { Herbicide }\left(\mathrm{T}_{7}\right)\end{array}$ \\
\hline \multicolumn{10}{|l|}{ Grains } \\
\hline Production & Kgs/ha & 1907 & 2264 & 2079 & 2507 & 2284 & 2626 & 2501 & 2734 \\
\hline Increase Over Check & $\%$ & - & 19 & 9 & 31 & 20 & 38 & 31 & 43 \\
\hline Income & Rs./ha & 8582 & 10,188 & 9,356 & 11,282 & 10,278 & 11,817 & 11,255 & 12,303 \\
\hline \multicolumn{10}{|l|}{ Stalks } \\
\hline Production & Kgs/ha & 5040 & 6267 & 5893 & 8773 & 6373 & 8160 & 7293 & 9000 \\
\hline Increase Over Check & - & - & 24 & 17 & 74 & 26 & 62 & 45 & 79 \\
\hline Income & Rs./ha & 1890 & 2350 & 2210 & 3290 & 2390 & 3060 & 2735 & 3375 \\
\hline Gross Income & Rs./ha & 10,472 & 12,538 & 11,565 & 14,571 & 12,668 & 14,877 & 13,989 & 15,678 \\
\hline Variable Costs & Rs./ha & 320 & 360 & 840 & 880 & 1,940 & 1,960 & 2,460 & 2,500 \\
\hline Net Benefit & Rs./ha & 10,152 & 12,178 & 10,725 & 13,691 & 10,728 & 12,917 & 11,529 & 13,178 \\
\hline Increase Over Check & $\%$ & - & 20 & 6 & 35 & 6 & 27 & 14.0 & 30 \\
\hline Cost-benefit Ratio & $\%$ & - & 50.67 & - & 2.91 & - & - & - & - \\
\hline
\end{tabular}

Note: $\operatorname{LSD}_{(0.05)}$ for Grain Yield $=316 \mathrm{Kgs} / \mathrm{ha}$

$\operatorname{LSD}_{(0.05)}$ for Stalk Yield $=1577 \mathrm{Kgs} / \mathrm{ha}$. 
Table 2

Relative Impact of Production Inputs on Net Benefits: Based on the Costs in 1997 and Projected Costs in 2003

\begin{tabular}{|c|c|c|c|c|c|c|c|c|c|}
\hline Variables & & $\begin{array}{l}\text { Check } \\
\left(\mathrm{T}_{8}\right)\end{array}$ & $\begin{array}{l}\text { Variety } \\
\text { Alone } \\
\left(\mathrm{T}_{1}\right) \\
\end{array}$ & $\begin{array}{c}\text { Herbicide } \\
\text { Alone } \\
\left(\mathrm{T}_{3}\right) \\
\end{array}$ & $\begin{array}{c}\text { Variety plus } \\
\text { Herbicide } \\
\left(\mathrm{T}_{5}\right)\end{array}$ & $\begin{array}{c}\text { Fertiliser } \\
\left(\mathrm{T}_{2}\right)\end{array}$ & $\begin{array}{c}\text { Variety plus } \\
\text { Fertiliser } \\
\left(\mathrm{T}_{4}\right)\end{array}$ & $\begin{array}{c}\text { Fertiliser plus } \\
\text { Herbicide } \\
\left(\mathrm{T}_{6}\right) \\
\end{array}$ & $\begin{array}{c}\text { Variety plus } \\
\text { Fertiliser plus } \\
\text { Herbicide }\left(\mathrm{T}_{7}\right)\end{array}$ \\
\hline \multicolumn{10}{|l|}{ Based on the Costs in 1997} \\
\hline Gross Income & Rs/ha & 11,425 & 13,670 & 12,605 & 15,825 & 13,810 & 16,190 & 15,240 & 17,045 \\
\hline Variable Costs & Rs/ha & 570 & 720 & 1,570 & 1,720 & 3,995 & 4,145 & 4,995 & 5,145 \\
\hline Net Benefit & Rs/ha & 10,885 & 12,950 & 11,035 & 14,105 & 9,815 & 12,045 & 10,245 & 11,900 \\
\hline Increase Over Check & $\%$ & - & 19.3 & 1.7 & 29.9 & -9.6 & 11.0 & -5.6 & 9.6 \\
\hline Cost-benefit Ratio & $\%$ & - & 13.77 & - & 1.55 & - & - & - & - \\
\hline \multicolumn{10}{|l|}{$\begin{array}{l}\text { Based on the Projected } \\
\text { Costs in } 2003\end{array}$} \\
\hline Gross Income & Rs/ha & 12,484 & 14,928 & 13,760 & 17,218 & 15,079 & 17,649 & 16,662 & 18,584 \\
\hline Variable Costs & Rs/ha & 1,015 & 1,440 & 2,934 & 3,362 & 8,227 & 8,766 & 10,142 & 10,588 \\
\hline Net Benefit & Rs/ha & 11,469 & 13,488 & 10,826 & 13,856 & 6,852 & 8,883 & 6,481 & 7,976 \\
\hline Increase Over Check & $\%$ & - & 18.0 & -6.0 & 21.0 & -40.0 & -23.0 & -43.0 & -30.0 \\
\hline Cost-benefit Ratio & $\%$ & - & 5.0 & - & 0.2 & - & - & - & - \\
\hline
\end{tabular}


input. In the area with more weeds, it would be better to combine herbicide with improved variety. The impact of the changes in the cost of production due to the changes in input prices in 1997, and the projected prices in 2003, revised analysis is presented in Table 2. It shows that the net benefit achieved by $\mathrm{T}_{1}$ to $\mathrm{T}_{7}$ are 19.3, -9.6 , 1.7, 11, 29.9, -5.6 and 9.6 percent, respectively in 1997 while 18.0, -40, -6.0, -23.0, 21, -43 and -30 , respectively in the year 2003.

The cost-benefit ratio of variety alone and its combination with herbicide is reduced and still acceptable during 1997 while during 2003 the CBR of variety plus herbicide was very low which may become uneconomical in the next year as the prices are rising. The CBR of variety alone during 2003 is 5 which is still acceptable. This shows that variety alone sustained over the years. Though fertiliser increased the yields significantly but its cost increased rapidly and therefore, according our study it will be beyond the reach of the farmers because of their socio-economic conditions.

\section{CONCLUDING REMARKS}

The seed of the improved variety is the only solution for the sustainability of the maize productivity in rainfed areas of Pakistan. The farmers should change their old low yielding variety to sustain at least 20 percent increase in net benefit with very low fluctuation in the cost of production over the years. This will help a lot in changing farmer's socio-economic conditions that will encourage the farmers for adoption of new technology as suggested by Brady (1990).

It is recommended that a viable and sustainable system of production and distribution of improved quality seed of maize should be in function in order to ensure sustainable maize production in the rainfed and other ecologies of Pakistan and elsewhere in the world.

Policy-makers, when making the policy, should take this point into consideration that the prices of the seed of improved variety/hybrids must be kept within the capabilities of the farmers.

Maize Scientists/Researchers should try to find out some low cost alternative methods of soil fertility and weed control, so that more productive and sustainable technology can be devised.

\section{REFERENCES}

Arain, A. S., S. M. Alam, and A. K. G. Tunio (1989) Performance of Maize Genotypes under Varying NP-fertiliser Environments. Sarhad Journal Agriculture 5:6 623626.

Balanos, J. (1998) Productivity with Conservation or Conservation with Productivity? A Critical Review of Sustainable Agriculture. Abstract- The 7th Asian Regional Maize Workshop, PCARRD. Los Balanos, Philippines, Feb. 23-27. 
Brady, N. C. (1990) Making Agriculture a Sustainable Industry. In C. A. Edwards, R. Lal, P. Madden, R. H. Miller, and G. House (eds) Sustainable Agricultural System. Ankeny IOWA: Soil and Water Conservation Society. 20-32.

Chand, A., and J. Longmire (1990) Chart Book of Maize in Pakistan and AJK. PARC/CIMMYT Paper No. 90-5: pp.105.

Chaudhry, G. A., G. Habib, M. Sadiq, and M. A. Khan (1989) Effect of Nitrogen. Phosphorus and Plant Population on Grain Yield of Dry Land Maize. J. Agric. Res. 27:1 19-29.

CIMMYT (1994) CIMMYT (1993-94) World Maize Facts and Trends. Seed Industries Revisited: Emerging Roles of the Public and Private Sectors. Mexico, D.F.

CIMMYT (1989) Maize Research and Development in Pakistan. Mexico, D.F.

Daskalou, G. (1986) The Evolution of Cereal Farming in Greece. The Long Journey Towards Self Sufficiency. (Options Mediterranean: 166-174). C.A.B. Maize Abstracts 4:5 310.

Dorich, R. A., H. L.Warren, D. M. Huber, and C. Tsai (1987) Inter-action of Corn Hybrids with Nitrogen Fertility. Down to Earth 43:2 18-24.

Dowswell, C. R. R. L. Paliwal, and R. P. Cantrell (1996) Maize in the Third World. Westview Press. pp. 268.

Firebaugh, F. M. (1990) Sustainable Agricultural System: A Concluding View. In C. A. Edwards, R. Lal, P. Madden, R. H. Miller, and G. House (eds) Sustainable Agricultural System. Ankeny IOWA: Soil and Water Conservation Society. 674676.

Javed, H. I., M. R. Malik, M. A. K. Tareen, H. N. Malik, and M. Aslam (1994) Evaluation Maize Production Technology in Low Rainfed Area (Fatehjang Tehsil). Sarhad Journal of Agriculture 10:3 217-222.

Khaliq, A., and M. Hussain (1984) Estimation of Losses Caused by Insects and Weed Pests to Maize Crop. Pak. J. Sci. Ind. Res. 30:8 622-623.

Okigbo, B. N. (1990) Sustainable Agriculture in Tropical Africa. In C. A. Edwards, R. Lal, P. Madden, R. H. Miller, and G. House (eds) Sustainable Agricultural System. Ankeny IOWA: Soil and Water conservation Society. 323-352.

Reeves, T. G. (1997) Food Security; Poverty Alleviation Natural Resource ProtectionAddressing Global Inequities through Agricultural Research Partnership. In CIMMYT Book of Abstracts. The Genetic and Exploitation of Heterosis in Crops. An International Symposium 12-22 August, Mexico, D.F.

Tareen, M. A. K., H. N. Malik, H. I. Javed, and M. Aslam (1990) Yield and Economic Returns with Different Weed Control Methods in Rainfed Maize. Pak. J. Weed Sci. Res 3:1 55-60. 


\section{Comments}

The subject of the maize production in the rainfed areas is a critical one, and the question of its sustainability deserves attention. There is interesting material in this paper on different production practices incorporated in different trails. It touches on important issue of increasing the maize grain and stalk production with respect to cost and benefits from the farmer's point of view but the subject does not come out clearly in the present structure of the paper.

First of all no description of the soil and weather conditions were mentioned which have a great impact on the productivity in the field. Secondly the paper is based on the output of the experiment with only one replication, no details of experimental design has been incorporated in the text. The statistical significance of different trails needs to be mentioned. The authors did not provide any evidence about the F-statistics, about the estimates of residual and sampling error terms, etc.; the accuracy and efficiency of the experiment cannot be perceived without proper statistical testing.

The results are presented in a fairly complicated manner. Especially, the use of variable cost is not clearly defined. It must show all the different activities and their respective costs used in order to estimate the variable costs. Additionally the estimates of variable costs used under Check (T8) and others (T1-T7) seems to be underestimated. The land preparation, seed, interculture and harvesting costs comes to about Rs 3625/Ha in Islamabad, in a study conducted by Chatha et al. (1987) as compared to the variable cost range from Rs 320/Ha to Rs 2500/Ha for T1-T8. The discrepancy in the calculation of variable costs have also severely effected the estimation of benefit cost ratio.

The study recommends the $\mathrm{T} 5$ to be the best practice, but allowing the cropping pattern on the fields of a common farmer, it does not seem Ok that the same output may be achieved (as perceived by the paper) on sustained basis for longer period without the use of fertiliser in this present era of intensive cropping pattern keeping in view the soil fertility. I hope these observations will help to improve the structure of the paper.

As already mentioned, in this paper issue of soil fertility is not considerably discussed. Since the paper recommends that the optimum way is, to use only improved variety of Maize, it greatly depend on the required nutrients availability in quite good amount, other agronomical, cultural and management practices. These practices needs further in depth look.

Finally no description of the procedure about the projection of the costs and benefits for the year 2003 is delineated. The assumption that costs of variable inputs 
will be increased at same rate as in 1997 may be misleading. For example, as is the case of fuel where this assumption becomes invalid due to significant price changes in past 5 years. Although it becomes complicated to go into such details but for the perception of realistic picture this is need of the time. It becomes more important because all the findings are stressing more on Cost-benefit ratio which otherwise is misleading. I hope these suggestions will help to improve the structure of the paper.

International Irrigation Management

Waqar A. Jehangir

Institute (IIMI), Lahore. 